University of Nebraska - Lincoln

DigitalCommons@University of Nebraska - Lincoln

Faculty Publications from the Harold W. Manter Laboratory of Parasitology

8-1950

\title{
A Preliminary Note on Trichinosis Investigations in Alaska
}

P. J. Brandly

United States Department of Agriculture

Robert L. Rausch

University of Washington, rausch@uw.edu

Follow this and additional works at: https://digitalcommons.unl.edu/parasitologyfacpubs

Part of the Parasitology Commons

Brandly, P. J. and Rausch, Robert L., "A Preliminary Note on Trichinosis Investigations in Alaska" (1950). Faculty Publications from the Harold W. Manter Laboratory of Parasitology. 500.

https://digitalcommons.unl.edu/parasitologyfacpubs/500

This Article is brought to you for free and open access by the Parasitology, Harold W. Manter Laboratory of at DigitalCommons@University of Nebraska - Lincoln. It has been accepted for inclusion in Faculty Publications from the Harold W. Manter Laboratory of Parasitology by an authorized administrator of DigitalCommons@University of Nebraska - Lincoln. 


\title{
A PRELIMINARY NOTE ON TRICHINOSIS INVESTIGATIONS IN ALASKA
}

\author{
By P. J. Brandly and Robert Rausch*
}

$\mathbf{T}$

Richinosis in the arctic regions of the world has received considerable attention during recent years, particularly since the work of Roth (1948) in Greenland. In Connell's (1949) review of arctic trichinosis some Alaskan and Canadian records were included but, until now, little has been known of the status of the disease in Alaska. Information available at the present time indicates that the incidence of trichinosis is high in circumpolar carnivores and that marine mammals have a definite place in its epizootiology. Present knowledge cannot explain the survival of trichinosis in marine manmal populations, but it is evident that they may serve as important sources of human infection.

The investigation of trichinosis and other animal-borne diseases in Alaska was instituted early in 1949 by the Alaska Health and Sanitation Activities, U.S. Public Health Service. P. J. Brandly directed the investigations until he resumed other duties in Washington, D.C. in October, 1949. Since that time R. Rausch has continued the work, and the addition of two parasitologists to the staff will allow a considerably expanded program during the field season of 1950 .

Facilities for trichinosis investigation were made available at Point Barrow through the generous cooperation of the Arctic Research Laboratory, and Rausch spent considerable time during the past year on the arctic coast in order to obtain material from marine mammals. Animal examinations have also been made in subarctic Alaska, where, in addition to specimens collected by the writers, much material has been made available by the Alaska Branch of the U.S. Fish and Wildlife Service. During 1949 more than 1200 specimens were examined.

The procedure for the determination of trichinosis in wild mammals has been as follows: suitable muscle tissue, preferably diaphragm, is examined microscopically for the presence of encysted larvae, and, if positive, a count is made to determine the number of larvae per gram of tissue. Regardless of the results of this examination, a 50 -gram sample of muscle tissue from each specimen is digested artificially at the U.S. Public Health Service Laboratory in Anchorage. A standard method of digestion of these samples, using synthetic gastric fluid, allows more critical observation and an accurate count to be made of larvae occurring in known amounts of infected tissue.

*U.S. Public Health Service, Anchorage, Alaska. P. J. Brandly was on temporary leave, 1948-1949, fron Production and Marketing Administration, Dairy Branch, U.S. Department of Agriculture, Washington, D.C. 
Up to the present time the following mammals from Alaska have been found to be infected:

From the arctic coast-polar bear, Thalarctos maritimus; arctic fox, Alopex lagopus inmuitus; red fox, Vulpes fulva alascensis; white whale, Delphinapterus leucas; Eskimo dog.

From south of the Brooks Range--brown and grizzly bears, Ursus spp.; wolf, Canis lupus ssp.; wolverine. Gulo l. luscus.

At the time of writing, nearly all species of land carnivores in Alaska have been examined as well as many other mammalian species less likely to be infected, including various rodents, shrews, and others. A detailed report of the findings will be made at a later date, when the number of examinations is considered significant.

Although infection of the white whale was suspected earlier in connection with an outbreak of trichinosis in Grecnland (Roth, 1948, p. 789 ), it is difficult, on the basis of present knowledge of the feeding habits of these animals, to understand how infection occurs. During the periodic peaks of lemming population density, large numbers are sometimes found in the water where, according to Elton (1942), they are often eaten by various fishes. It is possible that fish-eating whales or other marine mammals might become infected through eating, directly or indirectly, infected lemmings. However there has so far been no published record of naturally-occurring trichinosis in lemmings, and we have found no infection in the lemmings cxamined. Moreover, there does not appear to be any tendency towards cannibalism anong these rodents, by which means trichinosis might be transmitted from one animal to others. ${ }^{1}$ Rausch had the good fortune to observe a cyclic decline in lemmings (Lemmus) on the arctic coast during the spring of 1949. No cannibalism was in evidence, although dead animals were abundant and natural food (vegetation) was much reduced by the innumerable rodents. It is known that walrus will kill and eat seals, and it is possible that some of the other marine mammals also have a less restricted diet than is generally supposed. From present knowledge it would appear that trichinosis is endemic in marine mammals, even though the incidence may be relarively low when compared with land carnivores.

Although most of our work so far has been concerned with mammals other than man, it is of interest to note the results of a limited amount of skin testing of the people along the arctic coast. Of 70 adults tested in the village of Wainwright, 27 per cent reacted positively. A similar incidence was observed in Barrow village. Since marine mammals supply a large proportion of the natural food of these people, the possibility of

'T. H. Manning records cases of cannibalism in Lemmus trimucronatus in captivity, even when there was ample food available. Arctic Circular, Vol. 3, No. 2 (1950) p. 21. Ed. 
infections resulting from this source must be considered. The commonlyinfected polar bear is killed in numbers each year in both villages and is generally used for dog food. If intended for human consumption the meat is usually cooked. Limited observations on the grizzly bear indicate that the incidence of infection in this species is less than in the polar bear. The coastal natives occasionally secure grizzly bears, Ursus richardsoni ssp., but they are also more commonly used as dog food. The inland Eskimo kill several of these bears each year, but never eat the meat unless it is first cooked.

Studies in progress at the present time should disclose more complete information on the importance of animal-borne trichinosis and its relation to man in Alaska. Certainly the disease is of epizootic proportions in wild carnivores, and must have been established in them long before man was concerned. Uncritical observations made on the arctic coast suggest the possibility that the arctic strain of Trichinella might be more resistant to low temperatures than is the strain found farther south. Further work is being done on this at present. A greater knowledge of the epidemiology of the disease is necessary before the consideration of any plan for the prevention of trichinosis in the native people. It should be noted that caution must be exercised in the formulation of such a plan in order to avoid serious interference with the nutritional balance of the people in the Arctic.

\section{REFERFACES}

Connell, F. H. "Trichinosis in the Arctic: a revicw". Arctic, Vol. 2 (1949) pp. 98-107. EIton, Charles. "Voles, mice and lemmings', pp. 1-496, Oxford, 1942.

Thorborg, N. B., S. Tulinius, and H. Roth. "Trichinosis in Greenland". Acta Patb. et Microbiol. Scand. Vol. 25 (1948) pp. 778-794. 